\title{
Cytometric evidence reconciling the toxicity and usefulness of CTC as a marker of bacterial activity
}

\author{
Josep M. Gasol ${ }^{1, *}$, Javier Arístegui ${ }^{2}$ \\ ${ }^{1}$ Departament de Biologia Marina i Oceanografia, Institut de Ciències del Mar, CSIC, \\ Pg. Marítim de la Barceloneta 37-49, 08003 Barcelona, Spain \\ ${ }^{2}$ Facultad de Ciencias del Mar, Universidad de Las Palmas de Gran Canaria, Campus Universitario de Tafira, \\ 35017 Las Palmas de Gran Canaria, Spain
}

\begin{abstract}
To understand the opposing views on the utility of the CTC method, we examined bacterial abundance over incubations with the fluorogenic tetrazolium dye CTC (5-cyano-2,3-ditolyl tetrazolium chloride) and inspected the flow cytometric signatures of bacteria dually labeled with a DNA stain (Syto13) and CTC. Incubation of a marine plankton sample with CTC produced positive cells up to a stable value, reached in $<1 \mathrm{~h}$, while the red fluorescence of the granules increased for at least an extra hour. Incubation also produced a decrease in cell abundance of $22 \%$ after $30 \mathrm{~min}$ in the presence of $5 \mathrm{mM} \mathrm{CTC}$. The decrease was a function of CTC concentration and incubation time, and particularly affected bacteria with high nucleic acid content. Flow cytometric inspection of a doublestained (CTC and Syto13) sample showed that after $15 \mathrm{~min}$ of incubation, particles appeared having both red $(\mathrm{CTC}+)$ and green (DNA+) staining. Afterwards, other particles appeared that maintained the same light scatter properties and the red fluorescence, but that lost all green fluorescence. While the number of particles with double staining stabilized after about $1 \mathrm{~h}$, particles with red but without DNA staining increased for at least $100 \mathrm{~min}$. Simultaneously, the classic determination of CTC+ cells (observing only the red signal of the particles) increased as reported elsewhere. We interpreted these patterns as evidence of CTF (the formazan derivative of CTC) particles growing in the bacterial cells until they are so large that they break up the cells, after which they remain present as CTF granules with no associated cellular material. Microscopic or flow cytometric enumeration of red particles might still be a good indication of the percentage of bacterial cells having taken up and reduced the activity probe, but flow cytometric cell sorting of red particles based only on scatter and red fluorescence signals will select CTF particles without associated cellular material. Our results help reconcile the ecologically sound results and the CTC toxicity evidence currently reported in the literature, and lead to a warning against interpretations of cell sorting of CTC+ particles for phylogenetic or activity studies based only on red or orange fluorescence.
\end{abstract}

KEY WORDS: CTC $\cdot$ Syto13 $\cdot$ Flow cytometry $\cdot$ Cell sorting $\cdot$ Bacterial activity

\section{INTRODUCTION}

Microbial ecologists have long searched for a standardized method to unambiguously separate bacteria that are alive from those that are not, and those that participate in ecosystem metabolism and relate to community activity from those that do not. Hence, a large variety of methods have been introduced for probing the physiological status of individual bacteria, e.g. the direct viable count method (Kogure et al. 1987), microautoradiography (Meyer-Reil 1978), rRNA content (Karner \& Fuhrman 1997, Bouvier \& del Giorgio 2003), membrane-integrity probes (e.g. see list in Gasol \& del Giorgio 2000).

The introduction by Rodríguez et al. (1992) of a method that improved the capacity to probe bacteria 
possessing an active electron system revolutionized that quest. The method worked similar to the reduction by the electron transport system of INT (2-[4iodophenyl]-3-[4-nitrophenyl]-5 phenyl tetrazolium chloride) to a water-insoluble formazan crystal, a method that had been used to enumerate respiring planktonic bacteria (Zimmerman et al. 1978). In the modified method, the crystal was now fluorescent, and respiring cells provided with the fluorogenic tetrazolium dye CTC (5-cyano-2,3-ditolyl tetrazolium chloride) could reduce the crystal to a red-fluorescent formazan molecule that could easily be spotted, because of its red fluorescence, by epifluorescence microscopy or flow cytometry (del Giorgio et al. 1997, B. F. Sherr et al. 1999, Sieracki et al. 1999). Furthermore, the method targeted a process of great global significance: respiration. It was based on the same principle as a wellestablished protocol for measuring community respiration, the formazan-reduction ETS (electron transport system) measurement (Packard 1985), which had been shown to be correlated to microbial respiration both in fresh (del Giorgio 1992) and marine (Arístegui \& Montero 1995) waters. Both the ETS measure of system respiration and the CTC count of respiring bacteria were subsequently found to be positively correlated in at least 1 field study (Berman et al. 2001), and bacterial respiration was also seen to correlate with the amount of CTC-positive (CTC+) cells in another field study (Smith 1998). In another study, total red CTC fluorescence correlated with $\mathrm{CO}_{2}$ production in mixed bacterial assemblages in aerobic bioreactors (Cook \& Garland 1997).

This method has been used in a variety of different ecosystems since its introduction, and apparently ecologically coherent results have been found in most studies: the number of active bacteria and their contribution to total bacterioplankton community composition have been seen to increase with increasing lake trophic status (del Giorgio \& Scarborough 1995, Søndergaard \& Danielsen 2001), cell size (Gasol et al. 1995, Søndergaard \& Danielsen 2001) and predator activity (del Giorgio et al. 1996), with indications also that arctic bacteria can have high respiratory activities (Yager et al. 2001) and mesopelagic prokaryotes can also have relatively large respiration rates (Arístegui et al. 2005). The abundance of these active bacteria is often correlated with total bacterial production (Lovejoy et al. 1996, del Giorgio et al. 1997, B.F. Sherr et al. 1999) or with cell growth (Choi et al. 1996, 1999, E.B. Sherr et al. 1999), and the percentage of active bacteria is greater on particles than in free-living communities (B.F. Sherr et al. 1999, Yager et al. 2001, Sherr et al. 2002). Finally, the CTC technique has also been found appropriate for assessing the physiological status of benthic (Proctor \& Souza 2001, Haglund et al. 2002), groundwater (Hatzinger et al. 2003), biofilm (Yu \& McFeters 1994, Haglund et al. 2002) and soil (Winding et al. 1994, Whiteley et al. 2003) bacteria.

All these results seem to suggest that the method is valid and that it measures what it is supposed to measure (i.e. a certain degree of cellular activity). But some authors have opposed this claim, either because cellular toxicity of the CTC product occurred, or because low quantities of CTC+ cells were often encountered in field studies (Ullrich et al. 1999, Servais et al. 2001). It is rather obvious that the introduction of an electron acceptor that competes with oxygen in the ETS activity chain of a bacterium will affect the performance of the enzymes involved and, hence, bacterial growth. In fact, Ullrich et al. (1996) and Servais et al. (2001) showed inhibitory effects of CTC on bacterial respiration and metabolic activity. On the contrary, Epstein \& Rossel (1995) reported that CTC-stained and nonstained benthic bacteria grew equally well, and the formazan salt, albeit at a concentration $10 \%$ lower than the one commonly used, did not impair the ability of bacteria to grow or the ability of the ciliate Cyclidium sp. to predate and survive on a diet of CTC-stained bacteria. Based on flow cytometric sorting of redfluorescent particles (assumed to be bacteria which had reduced CTC) after incorporation of a radioactive tracer, Servais et al. (2001) concluded that 'the CTC dye is not suitable for the detection and enumeration of active bacteria (i.e. cells contributing to bacterial production)', since they calculated that the contribution of that bacterial fraction (i.e. CTC+) to total leucine uptake was only 27 to $57 \%$ of total bacterial leucine incorporation. Similar results were later reported by Longnecker et al. (2005).

The observations of Ullrich et al. (1996) and Servais et al. (2001), then, are at odds with the ecologically sound results enumerated above. To try to shed light on these contradictory observations, we explored here the effects of CTC toxicity, and whether these effects will impair our ability to detect those bacteria capable of reducing the formazan salt. We did so by measuring the evolution of bacterial abundance during CTC incubations and by observing the flow cytometric signatures of bacteria simultaneously labeled with CTC and a DNA stain (Syto13).

\section{MATERIALS AND METHODS}

Throughout, we designate as CTC+ particles scored as such after flow cytometric determination, whether they were cells or not (see following subsection). CTF is the red-fluorescing formazan derivative after reduction of CTC that takes the form of granules and stains a cell so that it belongs to the CTC+ population. 
Experiments. Water for almost all experiments was obtained from the harbor of Taliarte in the Bay of Melenara, eastern Gran Canaria Island, Spain. This is oligotrophic water, containing relatively high populations of Prochlorococcus $\left(6.2 \times 10^{4} \mathrm{ml}^{-1}\right.$ at the time of sampling) and lower concentrations of Synechococcus $\left(2.2 \times 10^{4} \mathrm{ml}^{-1}\right)$ and picoeukaryotes $\left(3.5 \times 10^{4} \mathrm{ml}^{-1}\right)$. The Taliarte harbor is very small, has little boat traffic and a sparse human population in the surroundings. Because of the volcanic origin of the islands, there is almost no shelf, and the water in the harbor reflects the oceanic nature of the surrounding water masses.

Overall experimental design consisted in the collection of seawater, the addition of CTC (Polysciences) at varying concentrations (0.5 to $10 \mathrm{mM}$, which reflects the range most commonly used in the past (Choi et al. 1996, 1999, Créach et al. 2003), incubation times varying between 10 min and $4 \mathrm{~h}$, and determination of total bacterial abundance and CTC+ (particles scored as positive by the method) abundance, along with their cellular characteristics (see 'Flow cytometric counts'). This was done by detecting the transformation of water-soluble CTC into water-insoluble CTC-formazan (CTF). To decrease the time scale of the bacterial response to CTC, on a few occasions we also added to the sample a filtrate of green alga culture at a dilution of $10 \%$ and then ran the experiments as above. Another batch of experiments included an initial addition of $10 \mu \mathrm{M}$ glucose and incubation of the samples for $30 \mathrm{~min}$; afterwards we followed the above-cited experimental design. Sometimes we preconditioned the samples by letting them stand overnight in the laboratory with or without additions. Expt 1 was designed to test the time response of CTC reduction with, or without, nutrient additions; Expt 2 was to describe the loss of bacterial cells after incubation with $\mathrm{CTC}_{\mathbf{i}}$ Expt 3 was to verify whether the cellular loss affected all types of bacterial cells equally; and Expt 4 was to describe the evolution, and to try to budget the disappearance of bacterial cells and the formation of $\mathrm{CTC}+$ particles at different CTC concentrations.

Cruise experiments. We also report data of bacterial and CTC+ cell abundance obtained during Cruise FAX99. The cruise was carried out in the coastal transition zone between the highly eutrophic waters of the NW Africa upwelling system and the nutrient-impoverished open ocean waters of the Canary Islands region, where the trophic conditions varied considerably. Samples for the experiments were collected from 2 depths (mixed layer and thermocline, usually $5 \mathrm{~m}$ and 40 to $80 \mathrm{~m}$ ) at 7 stations: 2 on the coastal shelf of NW Africa and the rest along an upwelling filament stretching towards the southern waters of the Canary Islands. Two replicate samples (5 $\mathrm{ml}$ each) -1 of them spiked with $\mathrm{NH}_{4} \mathrm{Cl}$ to a final concentration of $2 \mu \mathrm{M}-$ were left in the dark and at in situ temperature for ca. 1 to $2 \mathrm{~d}$ before the experiment was started. Two $1 \mathrm{ml}$ aliquots were spiked with $5 \mathrm{mM}$ final concentration of CTC and incubated 30 or 90 min in the dark in a regulated bath maintained at in situ temperature $\left( \pm 0.1^{\circ} \mathrm{C}\right)$. The samples were fixed with $1 \%$ paraformaldehyde $(\mathrm{PFA})+0.05 \%$ glutaraldehyde (final concentration), immediately frozen in liquid nitrogen and later stored at $-20^{\circ} \mathrm{C}$. An additional $0.5 \mathrm{ml}$ aliquot was fixed with PFA at Time 0 and spiked with $5 \mathrm{mM}$ final concentration of CTC for a background control of CTC fluorescence on dead samples. Bacterial and CTC+ abundances were determined by flow cytometry within months (see the following subsection).

Flow cytometric counts. A Becton Dickinson FACSCalibur flow cytometer was used for all abundance determinations. This is a standard instrument with a $15 \mathrm{~mW}, 488 \mathrm{~nm}$ argon laser, with a $70 \mu \mathrm{m}$ nozzle and flow rates ranging approximately from 12 to $60 \mu \mathrm{min}^{-1}$. We used Milli-Q water as sheath fluid, and counts were transformed to cell concentrations using an internal standard made of $0.92 \mu \mathrm{m}$ yellowgreen-fluorescing microbeads (Polysciences) added to the samples. Counts were later corrected by the dilution caused by the CTC solution and the added fixative.

CTC+ determinations by flow cytometry. We prepared daily batches of CTC at a $50 \mathrm{mM}$ concentration in Milli-Q water. We filtered them through $0.2 \mu \mathrm{m}$ polycarbonate filters, and stored them in the dark at $4^{\circ} \mathrm{C}$ until use. We rejected any CTC batch that had a yellow appearance when diluted in water, as, in our experience, this condition was associated with very long dissolution times and unreliable CTC+ determinations (see also Sherr et al. 2001). Batches with pinkwhite appearance and that dissolved faster were nonetheless filtered through $0.2 \mu \mathrm{m}$ before use. Incubations were performed in cryovial tubes or directly in the Falcon flow cytometry tubes, with total volumes ranging from 0.5 to $1.5 \mathrm{ml}$ of sample and an adequate volume of the CTC solution. Incubations were run at room temperature $\left( \pm 2^{\circ} \mathrm{C}\right.$ above in situ temperature, which was ca. $22^{\circ} \mathrm{C}$ ).

CTF is excited by wavelengths between 460 and $530 \mathrm{~nm}$ and fluoresces bright red. CTC+ particles were those that showed red fluorescence (above $630 \mathrm{~nm}$, FL3 in our instrument) above the background fluorescence level (del Giorgio et al. 1997, Sieracki et al. 1999). Thresholding was done in the red channel. A dual plot of $90^{\circ}$ light scatter and red fluorescence is enough to separate CTC+ cells from background noise (see Fig. 2B). However, we found that a FL2 (orange fluorescence)-FL3 (red fluorescence) plot was more useful because it allowed us to distinguish the populations of photosynthetic microbes (the prokaryotes 
Synechococcus and Prochlorococcus and the picoeukaryotes) from the CTC+ particles (see Fig. 8 in Gasol \& del Giorgio 2000). Red fluorescence and $90^{\circ}$ light scatter (SSC) were scaled to those values of the Polysciences beads added as an internal standard. Note that in normal flow cytometric detection of CTC+ 'bacteria', only CTF granules are detected.

Total bacterial abundance. Total bacterial counts were determined after staining with DMSO-diluted Syto13 (Molecular Probes) at $2.5 \mu \mathrm{M}$ (final conc.) for ca. $10 \mathrm{~min}$. Samples were run at low speed (approx. $12 \mu \mathrm{l}$ $\mathrm{min}^{-1}$ ) until $>20000$ events were acquired in log mode. Bacteria were detected by their signature in a plot of side scatter (SSC) versus green fluorescence (FL1), as previously suggested (Gasol \& del Giorgio 2000; see Fig. 2D,F). Thresholding was done in the green channel. In a plot of FL1 versus FL3 (red fluorescence), we could differentiate photosynthetic prokaryotes from non-photosynthetic prokaryotes in the cases where both were present. We separated bacteria containing high nucleic acid (HNA) from those containing low nucleic acid (LNA), as previously described (Gasol \& del Giorgio 2000) and based on the relative FL1 fluorescence of the different subpopulations. When we determined bacterial abundance with Syto13 after incubation with $\mathrm{CTC}$, thresholding was also done in the green channel, and we applied a higher voltage to the red photomultiplier (ca. twice the one applied to the green channel).

\section{RESULTS}

\section{Time response of CTC reduction}

In all the experiments, the CTC reduction time dynamics were similar to those described previously in the literature (e.g. Fig. 1, in Expt 1 where we used $5 \mathrm{mM}$ CTC). We report here just 1 example of the several similar experiments done. Following common procedures (del Giorgio et al. 1997, Sieracki et al. 1999, Gasol \& del Giorgio 2000), we consider CTC+ particles those that had red fluorescence and a certain degree of $90^{\circ}$ light scatter (SSC). Those 2 parameters increased with incubation time until reaching a plateau at about 100 min for SSC (Fig. 1C) and FL3 (Fig. 1B). The number of red particles reached a plateau after about $1 \mathrm{~h}$ (Fig. 1A) and did not increase afterwards, indicating that the particles were formed and identified early on, and they increased in size and fluorescence later on. Less than 50 min of incubation was enough to unambiguously detect the percentage of CTC+ bacteria in that particular experiment. The incubation of the sample with an algal filtrate increased the number of $\mathrm{CTC}+$ particles and consequently the percentage of

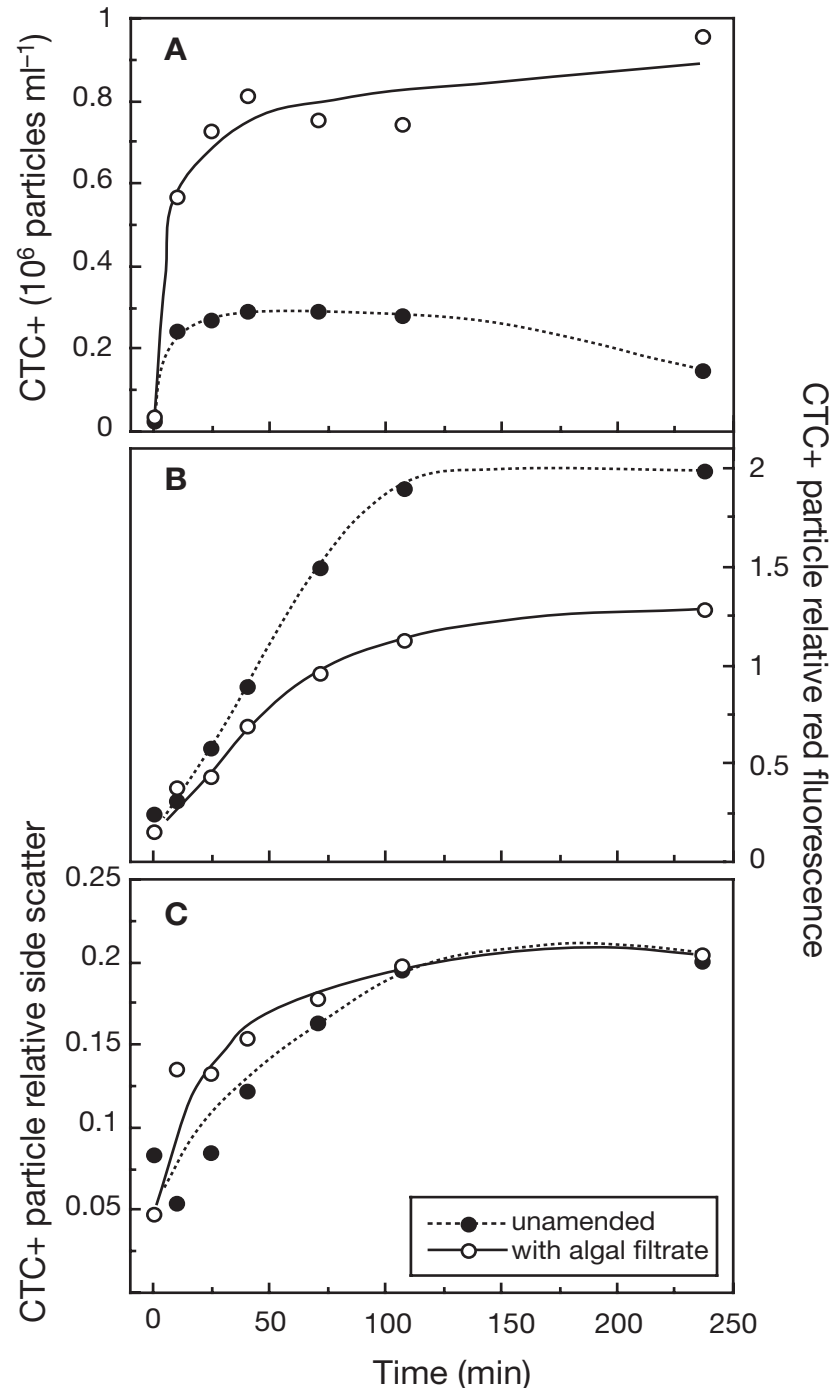

Fig. 1. Time evolution of a standard CTC (5-cyano-2,3-ditolyl tetrazolium chloride)-reduction experiment (Expt 1). Bacteria were either supplemented with an algal filtrate or unamended and preincubated overnight in the dark. The incubation with $5 \mathrm{mM}$ CTC lasted for a variable amount of time from 10 to 240 min. (A) Number of CTC+ particles (assumed to be cells), (B) CTC+ particle relative red fluorescence, and (C) CTC+ particle relative light scatter

CTC cells in the sample. Initially, the average red particles were larger (higher SSC), but had less fluorescence, indicating that the particles formed after incubation with the algal filtrate produced a larger but less fluorescent crystal. Subsequently, the increase in size of the crystals leveled off, while the difference in red fluorescence of the crystals was maintained. In this experiment, we obtained a percentage of CTC+ cells ranging from 20 to $40 \%$, a rather high proportion.

In this experiment, we also recorded the number of Syto13-stained cells after incubation, and noted that this number had decreased by $66 \%$ during the incubation without added algal filtrate and by $6 \%$ when the 
algal filtrate had been added. Microscopic enumeration of CTC+ particles is normally done under green light excitation, in which only the red fluorescence of the CTF granule (plus the algal autofluorescence) is visible. Thus, even with double staining (CTC plus the typical DNA stain DAPI), the fluorescence of the DAPI-DNA complexes is not detectable unless one switches the filters in the microscope. The red fluorescing particles should not be called CTC+ 'cells', as there is no evidence from the cytograms that they are indeed cells. Flow cytometric detection of CTC+ particles is commonly done in a plot of SSC versus FL3 (Fig. 2B), with or without additional inspection of an FL2 (orange) versus FL3 plot (del Giorgio et al. 1997, Sieracki et al. 1999, Gasol \& del Giorgio 2000). In our study, however, double staining with a DNA stain (such as Syto13) allowed detection of the bacteria via their green fluorescence (Fig. 2C,E). In this experiment, as well as in all others reported here, we observed that some of the green fluorescent particles acquired red fluorescence during incubation with CTC (Fig. 2D,F). No LNA cells seemed to acquire red fluorescence (Fig. 2D,F), but 2 well-defined clusters of HNA cells did.

\section{Effect of CTC concentration on the number of CTC+ cells and on the loss of bacteria}

Bacterial CTC reduction at different concentrations of the product also followed dynamics similar to those described by other authors (Expt 2; Fig. 3A). Maximum amounts of CTC+ particles were detected with 2 to $5 \mathrm{mM}$ of CTC. The use of lower concentrations resulted in lower amounts of CTC+ particles. Preconditioning of the samples in the dark for 0, 3 and $18 \mathrm{~h}$ did not affect the dynamics of CTC reduction, but the addition of glucose decreased the total number of CTC+ particles detected and the concentration at which this number was encountered. Preconditioning for $3 \mathrm{~h}$ increased total bacterial abundance without (9\%) or with (30\%) added glucose; a similar increase occurred with $18 \mathrm{~h}$ of preconditioning (5-fold increase in the control, 7 -fold increase in the glucose treatment). However, the abundance of bacteria in each treatment (i.e. with or without glucose, with different preconditioning times), relative to the initial values, decreased exponentially after 90 min of contact with the CTC product (Fig. 3B). This decrease was a function of both CTC concentration and the time the sample had spent in the dark (Fig. 3B). Glucose had no effect on the relative decrease in bacterial abundance. On average, we observed a $25 \%$ decrease in cell abundance when there was no dark preconditioning, 60 to $65 \%$ decrease when samples were preconditioned for $3 \mathrm{~h}$ and up to $94 \%$ decrease when samples were preconditioned for $18 \mathrm{~h}$.

\section{Loss of cells in experiments done during Cruise FAX99}

The decrease in bacterial abundance after incubation with CTC was also observed in samples collected during Cruise FAX99. There, we incubated samples from 28 stations with $5 \mathrm{mM} \mathrm{CTC}$ and fixed the samples after 30 or $90 \mathrm{~min}$ of incubation. After $30 \mathrm{~min}$ with CTC, the numbers of bacteria decreased on average $22 \%$ (Fig. 4A). Incubation over a longer (180 min) period did not significantly change the abundance of bacteria in the sample, although the percentage of CTC increased slightly (average $11.5 \pm 1 \%$ at $30 \mathrm{~min}$, average $15.2 \pm 2 \%$ after $90 \mathrm{~min}$ ). The concentration of CTC particles ranged from $1.9 \times 10^{4}$ to $6.7 \times 10^{5} \mathrm{ml}^{-1}$, with the percentage of CTC+ ranging from 3 to $35 \%$ of total counts. Bacterial concentrations after incubation were significantly correlated with abundance before incubation ( $\mathrm{p}<0.0005)$; the slope of the relationship was significantly $<1(0.87 \pm 0.06, p=0.03)$, indicating that there was a slight tendency for bacteria to disappear proportionally more frequently when bacterial abundances were higher than when they were lower. Similarly, the numbers of cells disappearing from the sample were correlated with the number of CTC+ particles (Fig. 4B), with a slope of 0.57. Again, this indicated that more bacteria disappeared when bacteria were, on average, more active than when they were less active. For this set of samples, we detected more bacteria disappearing than CTC+ particles appearing, but this was not always the case (see the following subsection).

\section{Loss of different types of bacterial cells caused by CTC}

Expt 3 was designed to observe whether the decrease in bacterial abundance at different CTC concentrations was similar for all types of bacteria (in terms of nucleic acid content). The decrease in cell abundance was mostly attributed to a decrease in HNA cells (Fig. 5). This observation concurs with the cytometric observations of red color development only in the HNA cells (Fig. 2D,F). Thus, CTC seemed to selectively kill cells that had a high nucleic acid content and were, presumably, active.

\section{Do all CTC+ cells disappear from the sample?}

From the cytometric inspection of red particle formation we could establish that some of the Syto13 greenstained cells evolved from being only green to become also red, and with time became red fluorescent, but no longer green fluorescent. These particles maintained 
large SSC, although they lost their green fluorescence (see Fig. 2D). The 3 such populations found could be distinguished as follows: (1) those that were stained with Syto13, but showed no CTC reduction, appeared
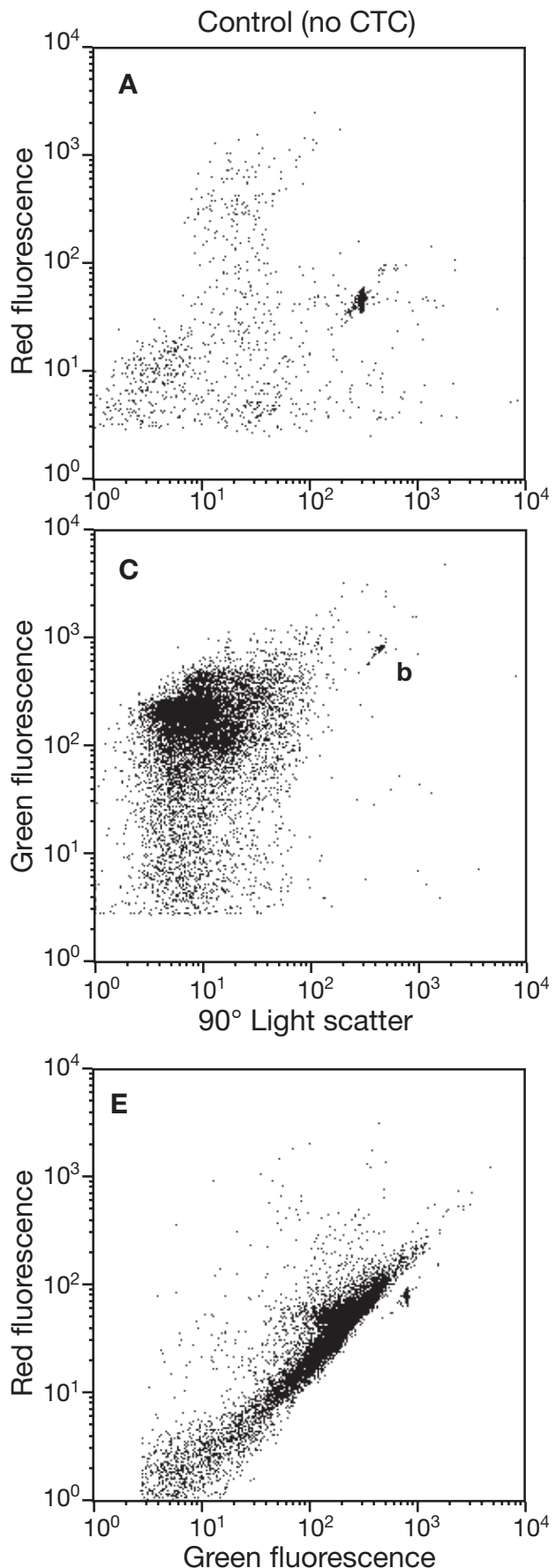

as green only, and were named green-positive, rednegative particles $(\mathrm{g}+/ \mathrm{r}-)$; (2) particles dually labeled with Syto13 and CTC, appeared both green and red, and were called green- and red-positive particles
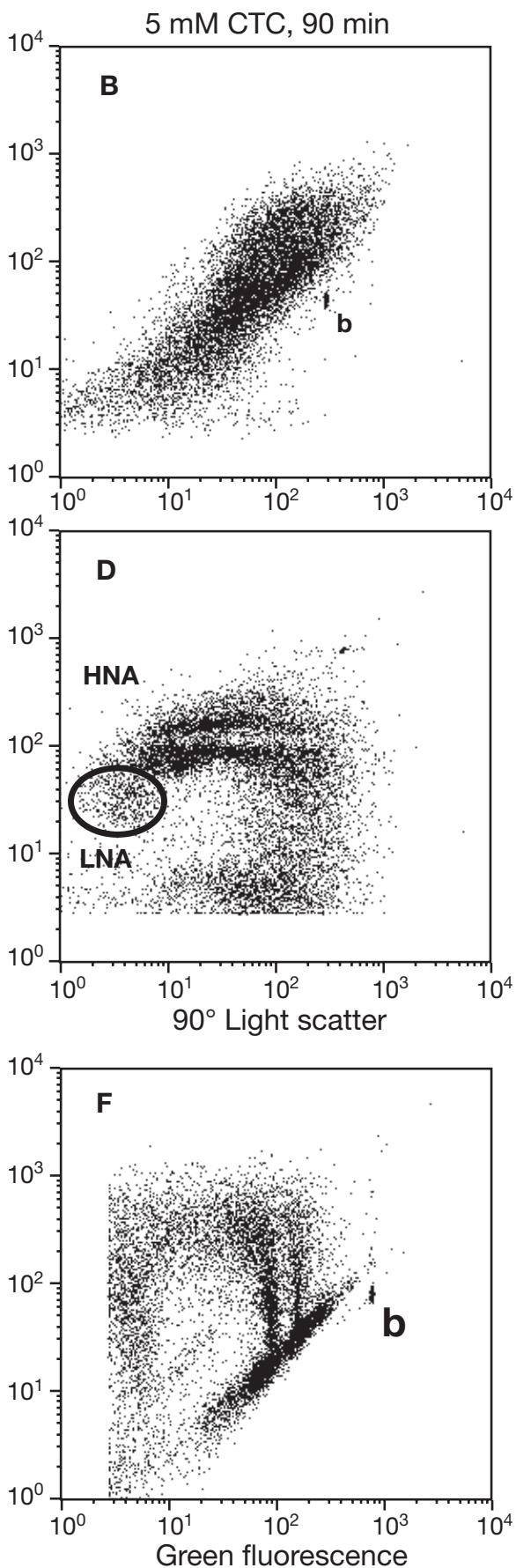

Fig. 2. Flow cytometric signatures of $(A, C, E)$ control (no CTC added) and (B,D,F) sample with 5 mM CTC added and incubated for 90 min during Expt 1. Each point represents a particle. (A) Sample not stained with Syto13, showing the plot of side scatter and red fluorescence without added CTC $;(B)$ sample not stained with Syto13, showing the plot of side scatter and red fluorescence with added CTC $;(C)$ sample stained with Syto13 without incubation with CTC (side scatter vs. green fluorescence); (D) sample stained with Syto13 and incubated with CTC (side scatter vs. green fluorescence); (E) sample stained with Syto13 without added CTC (red vs. green fluorescence); and (F) sample stained with Syto13 with incubation with CTC (red vs. green fluorescence). Population ' $\mathrm{b}$ ' represents the $0.92 \mu \mathrm{m}$ Polysciences yellow-green microbeads. The position of the low nucleic acid (LNA) bacteria is encircled, while the rest of the cells are the high nucleic acid (HNA) bacteria 


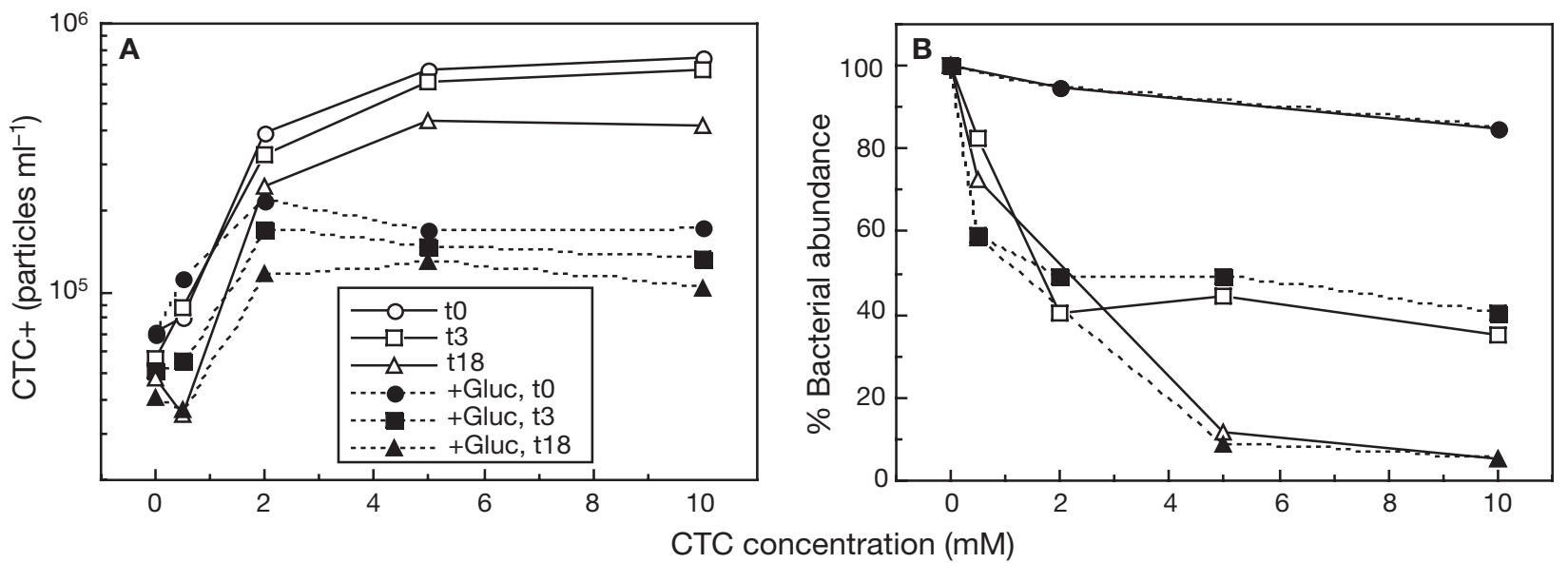

Fig. 3. (A) Evolution of the amount of CTC+ particles and (B) total bacteria after 90 min of incubation with different CTC concentrations (Expt 2). Total bacteria are expressed as a percentage of the bacterial abundance with no CTC added. Filled symbols correspond to samples that had been preconditioned with $1 \mu \mathrm{M}$ glucose for a period of time represented by the different types of symbols: $0 \mathrm{~h}$ (circles), $3 \mathrm{~h}$ (squares), or $18 \mathrm{~h}$ (triangles)

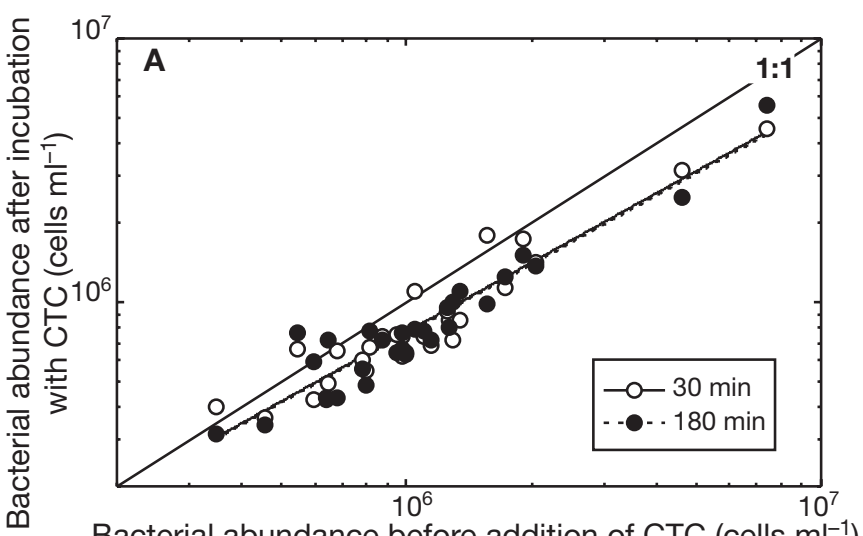

Bacterial abundance before addition of CTC (cells $\mathrm{ml}^{-1}$ )

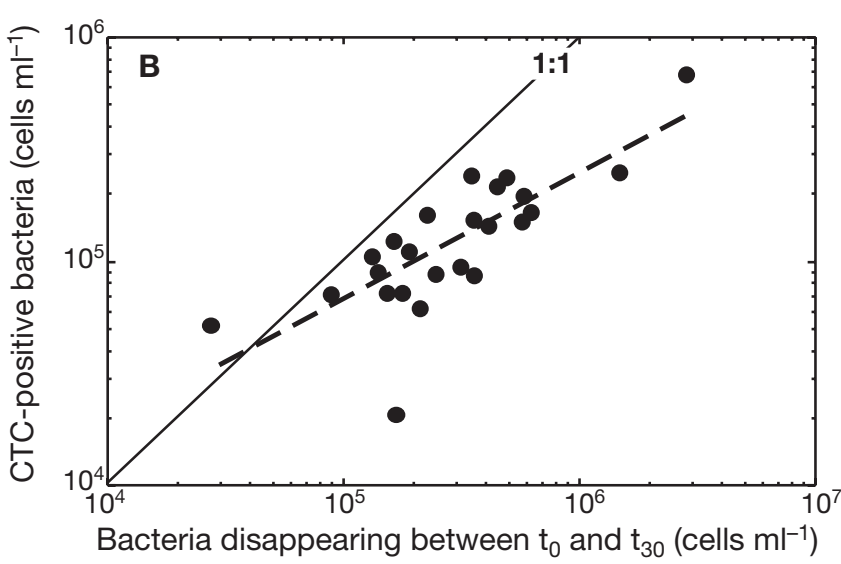

Fig. 4. (A) Relationship between bacterial abundance (BA) before incubation with CTC and after 30 min or 180 min incubation in samples from the central eastern Atlantic (Cruise FAX99). Relationships are best described by the equations Log BAafter $=0.63$ $+0.87 \times$ LogBAbefore, $\mathrm{n}=28, \mathrm{r}^{2}=0.96$ for $30 \mathrm{~min}$ and Log BAafter $=0.67+0.87 \times$ LogBAbefore, $\mathrm{n}=28, \mathrm{r}^{2}=0.95$ for $180 \mathrm{~min}$. $(\mathrm{B})$ Relationship between the detected CTC+ particles and the bacterial abundance disappearing (DBA) in 30 min incubations with CTC. The relationship can be described by the equation LogCTC $+=1.97+0.57 \times \operatorname{LogDBA}, \mathrm{n}=28, \mathrm{r}^{2}=0.82$. The $1: 1$ lines are shown in both panels

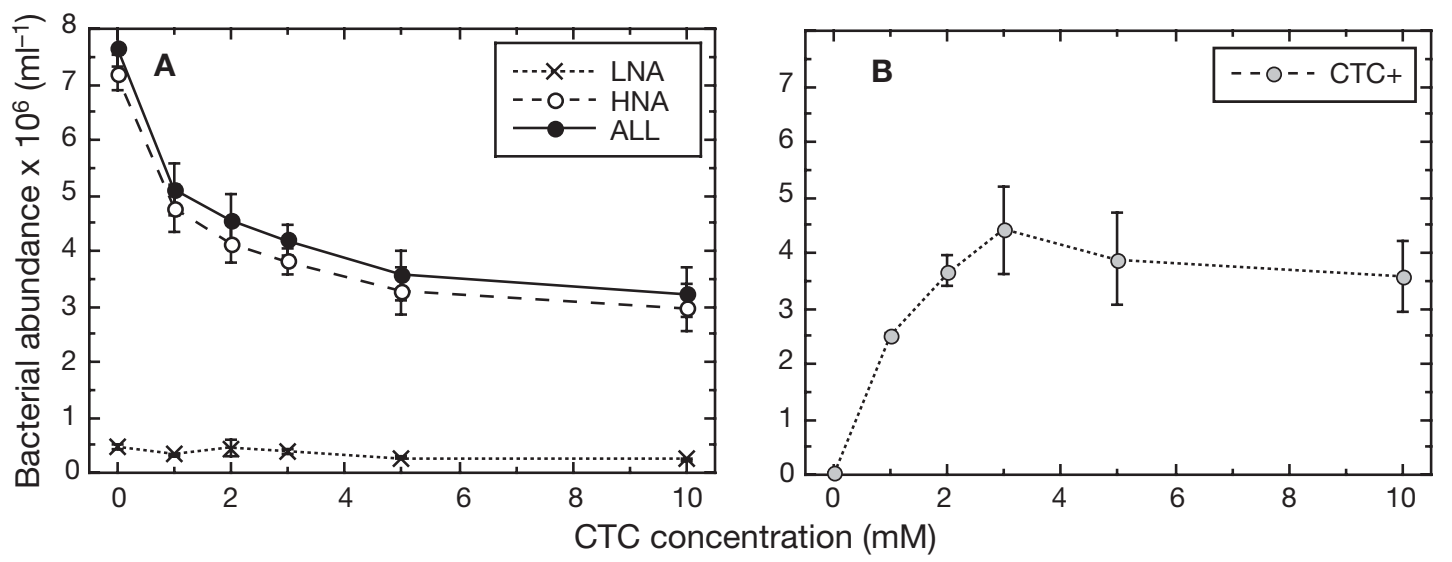

Fig. 5. (A) Disappearance of high nucleic acid containing bacteria (HNA), low nucleic acid containing bacteria (LNA) and total bacterial cells (ALL) in a 90 min incubation with CTC (Expt 3). (B) The corresponding increase in CTC+ particles in the same 

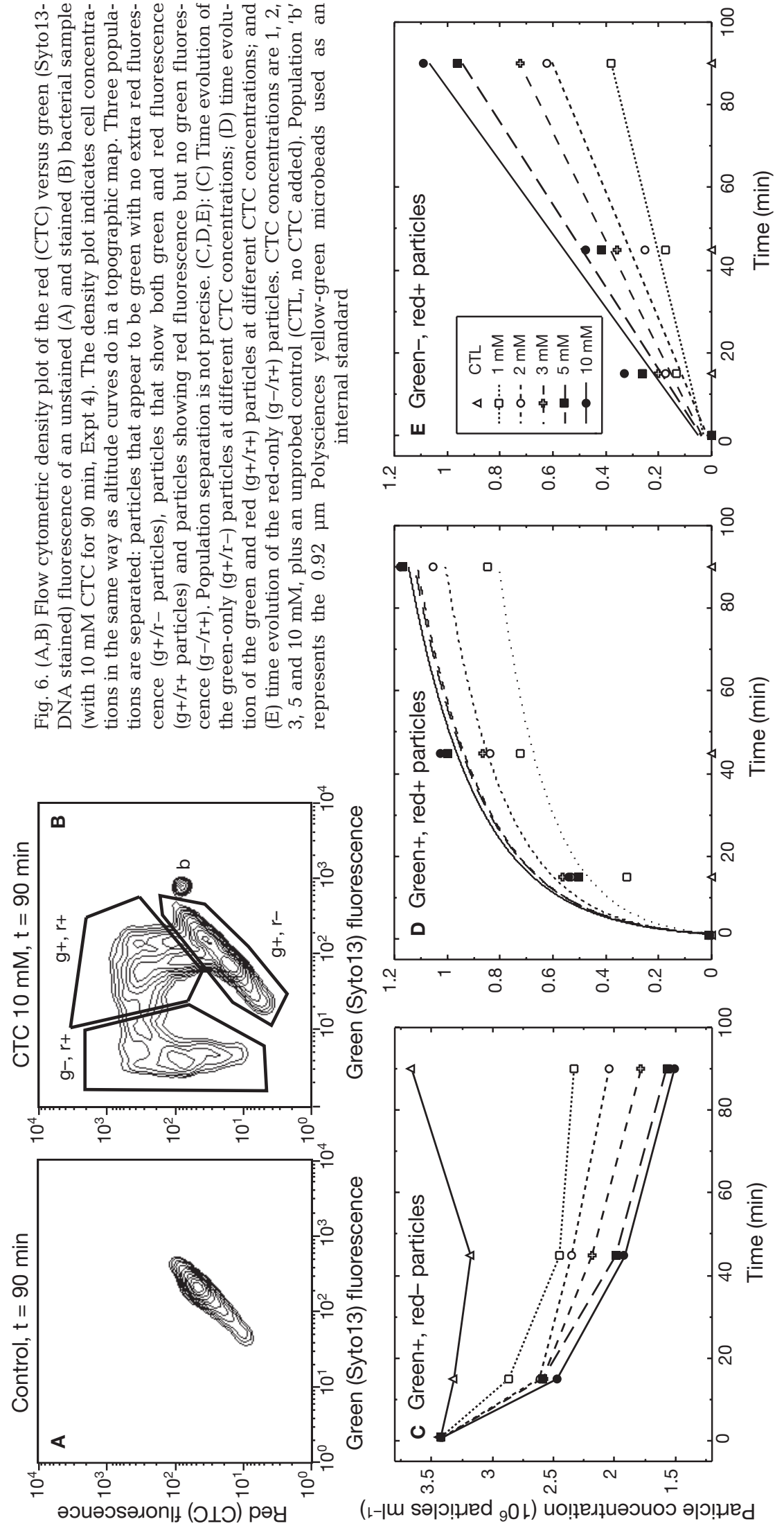

$(\mathrm{g}+/ \mathrm{r}+)_{i}$ (3) particles with only CTF and no associated green DNA fluorescence, named red-positive, greennegative particles $(\mathrm{g}-/ \mathrm{r}+)$. We then followed their changes over time and with different CTC concentrations (Fig. 6). Green-positive, red-negative cells (Fig. 6C) decreased in all treatments except the one with no CTC, and the decrease was faster with higher CTC concentrations. The disappearance seemed to stop after 60 min of incubation with CTC, as in the experiment reported in Fig. 4. The final number of cells after incubation with CTC varied from $70 \%$ of the untreated sample when $1 \mathrm{mM}$ was added, to $41 \%$ with the addition of 10 mM CTC. Particles with both green and red fluorescence developed following a logarithmic function that stabilized after approximately $1 \mathrm{~h}$ of incubation (Fig. 6D). We assume that this fit was the result of a process of input of particles to the $\mathrm{g}+/ \mathrm{r}+$ population added to a process of output in the form of $\mathrm{g}-/ \mathrm{r}+$ particles. All logarithmic fits were significant, with $\mathrm{r}^{2}>0.94$. The formation of red particles, with apparently no associated green fluorescence, was linear with time, with very good correlation (all $\mathrm{r}^{2}>0.95$ ) (Fig. 6E). The slopes (rate of particle formation) ranged from 3882 particles $\mathrm{min}^{-1}$ at the lower CTC concentration to 11277 particles $\min ^{-1}$ at the higher CTC concentration.

The gating of the sample (Fig. 6A,B) does not allow for a perfect budgeting of particle appearance and disappearance, but roughly 1 million cells disappeared with $10 \mathrm{mM} \mathrm{CTC} \mathrm{over} \mathrm{a} 90 \mathrm{~min}$ incubation period and 1 million redonly particles appeared (Table 1). In fact, the correspondence between the number of bacteria that disappeared and the number of red-only particles that appeared was highly significant (red particles $=98000+0.98$ 'missing cells' $, \mathrm{n}=12, \mathrm{r}^{2}=0.98$ ). Similarly, the number of red particles (with or without green) detected in the dually labeled samples was equivalent to the number of CTC+ detected with no additional nucleic acid staining 
Table 1. Abundance of each type of particle identified by flow cytometric inspection of dually labeled (CTC and Syto13) samples at different CTC concentrations during Expt 4. The types of particles are defined as in Fig. 6, except for $\mathrm{r}+$ particles, which represent the addition of $\mathrm{g}+/ \mathrm{r}+$ and $\mathrm{g}-/ \mathrm{r}+$ particles and 'missing cells', which indicate the difference between initial and final bacterial abundance. CTC+ particles are as identified in a plot of SSC versus FL3 fluorescence without additional Syto13 labeling (Fig. 2). Data are $10^{5}$ particles $\mathrm{ml}^{-1}$

\begin{tabular}{|c|c|c|c|c|c|c|}
\hline $\begin{array}{l}\text { CTC } \\
\text { conc. } \\
(\mathrm{mM})\end{array}$ & $\begin{array}{c}\text { Green- } \\
\text { only } \\
(g+/ r-)\end{array}$ & $\begin{array}{c}\text { Green \& } \\
\text { red } \\
(g+/ r+)\end{array}$ & $\begin{array}{l}\text { Red- } \\
\text { only } \\
(\mathrm{g}-/ \mathrm{r}+)\end{array}$ & $\begin{array}{l}\text { Missing } \\
\text { cells }\end{array}$ & $\mathrm{r}+$ & $\mathrm{CTC}+$ \\
\hline \multicolumn{7}{|c|}{ After 15 min incubation } \\
\hline 0 & 36.36 & 3.20 & 0.87 & 0.00 & 4.06 & 0.19 \\
\hline 1 & 31.56 & 6.75 & 2.36 & 2.42 & 9.11 & 13.89 \\
\hline 2 & 28.79 & 9.07 & 2.80 & 0.73 & 11.87 & 14.61 \\
\hline 3 & 28.40 & 9.38 & 3.11 & 1.83 & 12.49 & 14.89 \\
\hline 5 & 28.51 & 8.77 & 3.73 & 2.35 & 12.50 & 14.18 \\
\hline 10 & 27.18 & 9.16 & 4.51 & 3.59 & 13.67 & 14.04 \\
\hline \multicolumn{7}{|c|}{ After 90 min incubation } \\
\hline 0 & 40.21 & 1.62 & 0.80 & 0.00 & 2.42 & 0.21 \\
\hline 1 & 25.68 & 10.96 & 5.01 & 4.78 & 15.97 & 19.21 \\
\hline 2 & 22.55 & 13.23 & 7.64 & 7.27 & 20.87 & 20.77 \\
\hline 3 & 19.68 & 15.15 & 8.77 & 7.94 & 23.92 & 20.52 \\
\hline 5 & 17.30 & 14.49 & 11.38 & 9.93 & 25.87 & 20.25 \\
\hline 10 & 16.57 & 14.57 & 12.78 & 11.95 & 27.35 & 20.75 \\
\hline
\end{tabular}

(Table 1). During this experiment, the time dynamics of CTC+ detection were similar to those in Expt 1 (Fig. 1). Cell numbers stabilized more quickly (at $45 \mathrm{~min}$ ), while red fluorescence and SSC took longer to reach maximum values (with a plateau at $90 \mathrm{~min}$, although we did not take any further samples). The percentage of CTC in this experiment was rather high, ranging from 34 to $48 \%$ of bacterial abundance, and we assume this was due to the dark overnight incubation, although nothing had been added to the samples.

\section{DISCUSSION}

Since the introduction of the CTC reduction method by Rodríguez et al. (1992) as a means to detect actively respiring bacteria, the method has been applied to ecological questions in a variety of environments. There is an inherent beauty in the method because of the speed and ease of detection, which contrasts with other methods for probing the abundance of active and respiring microorganisms. Furthermore, the possibility of estimating total bacterial respiration from CTC+ abundance also has lured microbial ecologists. The method has also been adopted for the study of bacterial physiological responses to environmental conditions in a suite of strains and types of samples (see review in B.F. Sherr et al. 1999).
A variety of protocols have been used in the past (B.F. Sherr et al. 1999, Créach et al. 2003), and a consensus has emerged over which CTC concentrations and incubation times should be used, with 2 to $5 \mathrm{mM}$ of CTC being the concentrations of choice (Fig. 3A) and incubation times of $<1 \mathrm{~h}$ (Fig. 1). In accordance with previous studies (del Giorgio et al. 1997, Sieracki et al. 1999), we have noted that color development starts immediately after addition of CTC, so that detection of $\mathrm{CTC}+$ particles can already be carried out 10 min after CTC addition. However, as also noted previously, full formation of the CTF particle requires more time, usually up to 2-3 h of incubation (Fig. 1). Reports done in the past with protocols that differ from this 'consensus' protocol, such as with CTC concentrations that are too low (e.g. Lovejoy et al. 1996) or by flooding of filtercollected cells in a CTC solution (Karner \& Fuhrman 1997), have been regarded with suspicion (i.e. B.F. Sherr et al. 1999).

Detection and enumeration of cells with flow cytometry increases the possibilities of the method, making it even more attractive (del Giorgio et al. 1997, Sieracki et al. 1999): a large number of cells can be enumerated; sample volume can be kept to a minimum (and this is important given the price of the product); analysis time is reduced to a minimum; incubation time can also be reduced as the cells are detected earlier; plus additional statistical information, such as individual particle scatter (a proxy for CTF particle size) and red fluorescence can be easily retrieved. The combination of CTC+ abundance with average particle scatter and red fluorescence has been seen to correlate better with bacterial production than CTC+ abundance alone (B.F. Sherr et al. 1999). Furthermore, and as a general rule, more CTC+ cells are detected with flow cytometry than with epifluorescence microscopy (Sieracki et al. 1999), because of the higher sensitivity of the light detectors as compared to eye sensitivity.

As explained before (see 'Introduction'), many ecologically coherent results have been reported from CTC use. But, in spite of the many studies published, the method and its interpretation have been questioned (Ullrich et al. 1999). There are doubts over whether all bacteria can use CTC. While members of the presumably relevant oceanic lineages seem to use it without trouble (B.F. Sherr et al. 1999) and both aerobic and anaerobic bacteria can take up and reduce CTC (Smith \& McFeters 1997, Bhupathiraju et al. 1999), some bacteria seem to use it at very slow rates, or not to use it at all (Smith \& McFeters 1997, Hatzinger et al. 2003).

Other authors have criticized the method on the grounds that the number of CTC+ bacteria detected is often lower than active bacteria detected with other physiological probes (Karner \& Fuhrman 1997, Ullich 
et al. 1999). These differences have been attributed to the low detectability of the small CTF granules produced by small bacteria (use of flow cytometry could facilitate detection of all CTC+ particles). But relatively high values of the percentage of $\mathrm{CTC}+$ cells can also be measured, even in conditions of low expected bacterial growth. Yager et al. (2001) encountered an unprecedented $86 \%$ during a subzero Arctic algal bloom, and we measured values of $12 \%$ in open central Atlantic surface waters during Cruise FAX99 (Fig. 3), up to $8 \%$ in mesopelagic waters of the same region (Arístegui et al. 2005) and up to $48 \%$ in coastal Atlantic waters. The amounts of CTC+ particles, however, are considered to be at the lower limit of the amount of active bacteria measured with other indicators (e.g. Grossart et al. 2001). The CTC method has inherent variability, in the same way as other long-assumed activity probes, such as detectability with a general oligonucleotide probe (Karner \& Fuhrman 1997), have also recently been shown to be methodologically variable (Bouvier \& del Giorgio 2003). Newer methods might replace CTC as a probe for activity.

Another criticism of the CTC method arises from its toxicity to bacteria. CTC has been shown to deter bacterial growth and activity (Ullrich et al. 1996, Grossart et al. 2001, Servais et al. 2001). The effect was reported to be instantaneous upon addition of the product for assays such as leucine incorporation (Servais et al. 2001) and motility (Grossart et al. 2001). We have also shown that there is an apparent cell disintegration upon contact with CTC (Figs. 2 to 6), with up to $90 \%$ of the cells in some cases (Fig. 3B), a phenomenon detected in oceanic (Fig. 3) as well as in coastal bacterial communities. The effect occurs even at concentrations of CTC of $0.5 \mathrm{mM}$ (Fig. 3) and is evident after only 10 min of incubation (Fig. 6). We noted that the bacteria disintegrated more readily if they were in the middle of the growth cycle: samples that had been preincubated in the dark, even without substrate additions, had the higher disintegration rates (Fig. 4). We also found that the bacteria with higher nucleic acid content disintegrated more rapidly (Fig. 5).

This evidence of toxic CTC effects is more a perceived than a real drawback of the method, since a product that interferes with the electron transport system is bound to alter bacterial metabolism. The toxic effects are posterior to the incorporation and reduction of CTC, and thus they would not per se invalidate them. The fact that we, and others (del Giorgio et al. 1997, Sieracki et al. 1999), have observed that the intracellular reduction (the red fluorescence) continues after the number of CTC+ cells stabilizes (Fig. 1) indicates that not all cells are killed instantly, but rather many continue to function hours after exposure to CTC. In a study combining microautoradiography, flu- orescent in situ hybridization and CTC, Nielsen et al. (2003) found that all cells labeled with CTC were also labeled as positive by the other 2 techniques, thus discrediting the idea that CTC toxicity would impair the ability of scoring these cells as positive.

A more serious concern on the validity of the CTC method was noted after cell sorting of radioactivity-labeled cells. Servais et al. (2001) observed that even though the average cell-specific activity of the sorted $\mathrm{CTC}+$ fraction was higher than that of the total bacterial community, the activity represented by the CTC+ fraction was 27 to $57 \%$ of total activity, thus suggesting that most bacterial activity was not in that CTC+ fraction, assumed to be cells. Similar results were found by Longnecker et al. (2005) using the same approach in the NW Pacific. Our results, however, suggest that these results may not reflect the real activity of the cells having reduced CTC. As others have done, these authors sorted CTC+ particles from a plot of red versus orange fluorescence (see Fig. 2 in Longnecker et al. 2005, as an example) and had, thus, no evidence that the red particles being sorted were indeed bacteria. If some of the particles had no associated cellular material, then the radioactivity associated with the red particles would be lower than it should be. As the radioactivity of this sample was compared to that of the total community, unstained with CTC, the percent contribution of that fraction would be even smaller than it should be. Furthermore, if the most active bacteria were the ones disintegrating, then this value would be underestimated.

In a previous study in which we identified CTC+ by their red fluorescence and sized the DAPI image of each cell (Gasol et al. 1995), we encountered extracellular red crystals that we assigned to abiotic CTC reduction, known to occur in some situations (e.g. Schaule et al. 1993). However, our current cytometric data suggest that these red granules were the result of previously respiring cells (see Fig. 6), also because the numbers of red particles fit well with the number of cells that had disappeared (Table 1). In another case (Fig. 3B), there were more disappearing cells than red particles produced, but this may have been due to the green triggering in our counting protocol, which would miss lightly fluorescent red particles if they are not associated with green fluorescence. Servais et al. (2001) also found some evidence of CTC released or lost by respiring cells after a certain period of incubation, but they did not explore this observation further. Extracellular CTF crystals have also been noted in some laboratory studies (Caro et al. 1999), while other authors have specifically stated that no granules without cells were detected (Søndergaard \& Danielson 2001). In some reported counting protocols it has clearly been stated that each bacteria should be double checked for DAPI and CTC staining if inspected by 
epifluorescence (Choi et al. 1996, 1999, B.F. Sherr et al. 1999, E.B. Sherr et al. 1999). But there is an important difference between the common practice for CTC enumeration with epifluorescence microscopy and flow cytometry, which is the fact that microscopy samples are commonly counterstained with DAPI or AO, while flow cytometry samples are not (Sherr et al. 2001). We were able to detect this cellular disintegration effect of CTC because we double stained the samples with a DNA stain, Syto13, simultaneously with the activity probe; this allowed us to follow the evolution of the cells that had taken up CTC and become dually labeled with green and red (Figs. 2 \& 6). Then, and following very clear kinetics, the cells became red particles with no associated green fluorescence. The cytograms also show that the scatter signal (assumed to represent particle size) lasts for a short time, but subsequently this signal, as well as the red signal, tends to decrease in intensity (see Fig. 2: the red signal seems to originate at a high SSC value and when it is formed tends to decrease and accumulate at SSC values placed at channels $<100$ ). This observation is compatible with our interpretation of cellular disintegration throughout the process.

The effect that we observed also seems to occur when the cells are counterstained with DAPI (J. Iriberri \& A. Latatu pers. comm.). But the possibility exists that the detected pattern could be due to increased quenching of green fluorescence by red CTC fluorescence. Swannell \& Williamson (1988) observed that INT+ cells could not be counterstained with DAPI, malachite green, or auramine, as the INT crystal quenched the stains' fluorescence. These same authors did not find this problem when using ethidium bromide, due to its higher affinity for DNA. Similarly, Zimmermann et al. (1978) used acridine orange as a counterstain without apparent problems. If anything, we think that the green Syto13 fluorescence will quench the CTF red fluorescence and not the other way around (see also Haglund et al. 2002), as the relative fluorescence of a Syto13-stained cell is much higher than that of a CTC-labeled cell. Bhupathiraju et al. (1999) also suggested that in both pure-culture and environmental samples, the intercalation of DAPI with bacterial nucleoids attenuated the fluorescent signal emitted from CTC-formazan precipitates. Inspection of Figs. $2 \& 6$ suggests that we are dealing with cell disintegration and not with fluorescence quenching. Cell sorting of the $\mathrm{g}-\mathrm{r}+$ particles followed by microscopic inspection could resolve the question in the future.

We believe that our observations have not previously been reported, because inspecting each CTC+ particle for counterstaining is tedious (but see Choi et al. 1996, 1999, E.B. Sherr et al. 1999). Furthermore, our samples were from an oligotrophic site and had been allowed to grow for a few hours or had been supplemented with glucose and/or algal extract. We suspect that these procedures caused unbalanced bacterial growth and high respiration rates in small bacteria, resulting in a CTF granule that broke the cell. Large bacteria, such as the benthic bacteria that Epstein \& Rossell (1995) used for their experiments, or most coastal and freshwater bacteria may well be large enough to accommodate a large CTF granule (or even $>1$ crystal cell $^{-1}$ if they are sufficiently large; Nielsen et al. 2003) without cell breakage. It is important to mention here that the relationship between 'missing cells' and red-only particles reported in Fig. 6 (slope: 0.98, $\mathrm{r}^{2}=0.98$ ) suggests that most of the time only 1 crystal cell ${ }^{-1}$ was produced.

Furthermore, in spite of the ability of many bacterial strains to use CTC (B.F. Sherr et al. 1999), the possibility exists that variability occurs in the rates of uptake related to the phylogenetic composition of the samples. del Giorgio \& Bouvier (2002) presented data that implies differences in the use of CTC in the limnic versus the marine part of an estuary, perhaps linked to the presence/absence of Betaproteobacteria. Similarly, bacteria in particles seem to be much more active than planktonic bacteria (e.g. 19 to $35 \%$ in CTC as compared to $2-7 \%$ in plankton; B.F. Sherr et al. 1999), and it has been shown that bacterial phylogenetic composition in particles tends to be dominated by bacteria of the Bacteroidetes and Gammaproteobacteria groups, while those phylotypes are not as common in the plankton. Inspection of the dually labeled sample (Fig. 2) suggests that only a few subgroups (maybe just 2) take up CTC. Whether those are specific bacteria is unknown, but this is a worthwhile avenue of future research.

It is known that cells can reduce any quantity of reductant, from a single CTC molecule up to a level that is well above the red detection threshold. On top of that continuum, there is probably a continuum of cellular sensitivity to CTC toxicity. In any case, the groups that took up the CTC belonged to the HNA bacteria, considered to be the most active fraction of the bacterial community, at least in coastal environments (Lebaron et al. 2001). This is in agreement with other studies in which it has been shown that all CTC+ bacteria also scored as positive in other bacterial activity probes, such as formation of capsules (Storedegger \& Herndl 2002) or microautoradiography (Nielsen et al. 2003). The opposite (i.e. that the cells scoring as negative in these methods would also score as $\mathrm{CTC}+$ ) has never been reported.

Apart from the above specific concerns with the flow cytometric analysis of CTF particles believed to include all CTC+ bacteria, studies that use flow cytometric sorting of CTC+ bacteria for phylogenetic analysis of the presumably active portion of the bacterioplankton community (e.g. Bernard et al. 2001, 
Whiteley et al. 2003, Longnecker et al. 2005) might also be in doubt, particularly if cell sorting was done without double staining and without external confirmation of the assignment to bacteria of the sorted red particles. Similarly, the combination of identity probes with CTC might miss some of the phylotypes that take up and reduce the activity probe if extracellular CTF granules are detected, although this did not seem to be the case in the only paper to date that used this approach (Nielsen et al. 2003).

We have presented results that confirm some of the regularities previously described for the measurement of CTC+ bacteria in the marine environment with flow cytometry. Furthermore, we present a hypothesis that would explain some of the reported CTC toxicity, by which some cells would take up CTC, create a CTF granule and then release this granule with associated cell disintegration. The implications of this hypothesis are that cell sorting of CTF particles based only on their red and/or orange fluorescence would not be representative of the activity and phylogeny of the cellular subfraction that took up and reduced the probe. Based on the good correlation between bacterial production and CTC reduction, B.F. Sherr et al. (1999) suggested that the bulk of leucine incorporation was due to CTC+ bacteria. Other evidence has also been published consistent with CTC being a good indicator of bacterial viability, e.g. CTC+ and nucleoid-containing bacteria were correlated with ETS activity, but total bacterial count was not (Berman et al. 2001). Data like these would be at odds with the evidence presented by Servais et al. (2001) and Longnecker et al. (2005). Our results offer an alternative interpretation and indicate that the B.F. Sherr et al. (1999) contention may still be valid.

None of the current methods for the absolute detection of active cells in plankton provides an ideal probe for cell viability. Consensus is growing in that natural bacterial communities present a whole range of individual activities that can not be recovered by any single method (Gasol \& del Giorgio 2000, Smith \& del Giorgio 2003), among these, however, the CTC method may still produce data useful for the testing of ecological questions.

Acknowledgements. The authors were supported by Spanish MCyT projects RODA and MODIVUS (CTM2005-04795/ MAR), by the EU Contract BASICS (EVK3-CT-2002-00078). This is also a contribution to the EU NoE MARBEF. We thank T. Bouvier, C. Lovejoy, J. Pinhassi, K. Šimek, X. Morán, D. Vaqué and 2 anonymous reviewers for helpful comments.

\section{LITERATURE CITED}

Arístegui J, Montero MF (1995) The relationship between community respiration and ETS activity in the ocean. J Plankton Res 17:1563-1571
Arístegui J, Duarte CM, Gasol JM, Alonso-Sáez L (2005) Active mesopelagic prokaryotes support high respiration in the subtropical Northeast Atlantic Ocean. Geophys Res Lett 32, LO3608, doi:10.1029/2004 GLO21863

Berman T, Kaplan B, Chava S, Viner Y, B.F. Sherr, E.B. Sherr (2001) Metabolically active bacteria in Lake Kinneret. Aquat Microb Ecol 23:213-224

Bernard L, Courties C, Duperray C, Schäfer H, Muyzer G, Lebaron P (2001) A new approach to determine the genetic diversity of viable and active bacteria in aquatic ecosystems. Cytometry 43:314-321

Bhupathiraju VK, Hernandez M, Landfear D, Alvarez-Cohen L (1999) Application of a tetrazolium dye as an indicator of viability in anaerobic bacteria. J Microbiol Methods 37: 231-243

Bouvier T, del Giorgio PA (2003) Factors influencing the detection of bacterial cells using fluorescence in situ hybridization (FISH): a quantitative review of published reports. FEMS Microbiol Ecol 44:3-15

Caro A, Got P, Baleux B (1999) Physiological changes of Salmonella typhimurium cells under osmotic and starvation conditions by image analysis. FEMS Microbiol Lett 179:265-273

Choi JW, E.B. Sherr, B.F. Sherr (1996) Relation between presence-absence of a visible nucleoid and metabolic activity in bacterioplankton cells. Limnol Oceanogr 41:1161-1168

Choi JW, B.F. Sherr, E.B. Sherr (1999) Dead or alive? A large fraction of ETS-inactive marine bacterioplankton cells, as assessed by reduction of CTC, can become ETS-active with incubation and substrate addition. Aquat Microb Ecol 18:105-115

Cook KL, Garland JL (1997) The relationship between electron transport activity as measured by CTC reduction and $\mathrm{CO}_{2}$ production in mixed microbial communities. Microb Ecol 34:237-247

Créach V, Baudoux A-C, Bertru G, Le Rouzic B (2003) Direct estimate of active bacteria: CTC use and limitations. J Microbiol Methods 52:19-28

del Giorgio PA (1992) The relationship between ETS (electron transport system) activity and oxygen consumption in lake plankton: a cross-system calibration. J Plankton Res 14: 1723-1741

del Giorgio PA, Bouvier TC (2002) Linking the physiologic and phylogenetic successions in free-living bacterial communities along an estuarine gradient. Limnol Oceanogr 47:471-486

del Giorgio PA, Scarborough G (1995) Increase in the proportion of metabolically active bacteria along gradients of enrichment in freshwater and marine plankton: implications for estimates of bacterial growth and production rates. J Plankton Res 17:1905-1924

del Giorgio PA, Gasol JM, Vaqué D, Mura P, Agustí S, Duarte CM (1996) Bacterioplankton community structure: protists control net production and the proportion of active bacteria in a coastal marine community. Limnol Oceanogr 41: 1169-1179

del Giorgio PA, Prairie YT, Bird DF (1997) Coupling between rates of bacterial production and the abundance of metabolically active bacteria in lakes, enumerated using CTC reduction and flow cytometry. Microb Ecol 34:144-154

Epstein SS, Rossel J (1995) Methodology of in situ grazing experiments: evaluation of a new vital dye for preparation of fluorescently labeled bacteria. Mar Ecol Prog Ser 128: $143-150$

Gasol JM, del Giorgio PA (2000) Using flow cytometry for counting natural planktonic bacteria and understanding the structure of planktonic bacterial communities. Sci Mar 64:197-224 
Gasol JM, del Giorgio PA, Massana R, Duarte CM (1995) Active versus inactive bacteria: size-dependence in a coastal marine plankton community. Mar Ecol Prog Ser 128:91-97

Grossart HP, Riemann L, Azam F (2001) Bacterial motility in the sea and its ecological implications. Aquat Microb Ecol 25:247-258

Haglund AL, Törnblom E, Boström B, Tranvik L (2002) Large differences in the fraction of active bacteria in plankton, sediments and biofilm. Microb Ecol 43:232-241

Hatzinger PB, Plamer P, Smith RL, Peñarrieta CT, Yoshinari T (2003) Applicability of tetrazolium salts for the measurement of respiratory activity and viability of groundwater bacteria. J Microbiol Methods 52:47-58

Karner M, Fuhrman JA (1997) Determination of active marine bacterioplankton: a comparison of universal 16S rRNA probes, autoradiography, and nucleoid staining. Appl Environ Microbiol 63:1208-1213

Kogure K, Simidu U, Taga N, Colwell RR (1987) Correlation of direct viable counts with heterotrophic activity for marine bacteria. Appl Environ Microbiol 53:2332-2337

Lebaron P, Servais P, Agogué H, Courties C, Joux F (2001) Does the high nucleic acid content of individual bacterial cells allow us to discriminate between active cells and inactive cells in aquatic systems? Appl Environ Microbiol 67:1775-1782

Longnecker K, B.F. Sherr, E.B. Sherr (2005) Activity and phylogenetic diversity of bacterial cells with high and low nucleic acid content and electron transport system activity in an upwelling ecosystem. Appl Environ Microbiol 71: 7737-7749

Lovejoy C, Legendre L, Klein B, Tremblay JÉ, Ingram RG, Therriault JC (1996) Bacterial activity during early winter mixing (Gulf of St. Lawrence, Canada). Aquat Microb Ecol 10:1-13

Lovejoy C, Legendre L, Therriault JC, Tremblay JÉ, Klein B, Ingram RG (2000) Growth and distribution of marine bacteria in relation to nanoplankton community structure. Deep-Sea Res II 47:461-487

Meyer-Reil LA (1978) Autoradiography and epifluorescence microscopy combined for the determination of number and spectrum of actively metabolizing bacteria in natural waters. Appl Environ Microbiol 36:506-512

Nielsen JL, de Muro MA, Nielsen PH (2003) Evaluation of the redox dye 5-cyano-2,3-tolyl-tetrazolium chloride for activity studies by simultaneous use of microautoradiography and fluorescence in situ hybridization. Appl Environ Microbiol 69:641-643

Packard TT (1985) Measurement of electron transport activity of microplankton. Adv Aquat Microbiol 3:207-261

Proctor LM, Souza AC (2001) Method for enumeration of 5cyano-2, 3-ditolyl tetrazolium chloride (CTC)-active cells and cell-specific CTC activity of benthic bacteria in riverine, estuarine and coastal sediments. J Microbiol Methods 43:213-222

Rodríguez GG, Phipps D, Ishiguro K, Ridgway HF (1992) Use of a fluorescent redox probe for direct visualization of actively respiring bacteria. Appl Environ Microbiol 58: 1801-1808

Schaule G, Flemming HC, Ridgway HF (1993) Use of 5cyano-2,3-ditolyl tetrazolium chloride for quantifying planktonic and sessile respiring bacteria in drinking water. Appl Environ Microbiol 59:3850-3857

Servais, P, Agogué H, Courties C, Joux F, Lebaron P (2001) Are the actively respiring cells (CTC+) those responsible for bacterial production in aquatic environments? FEMS Microbiol Ecol 35:171-179
B.F. Sherr, del Giorgio PA, E.B. Sherr (1999) Estimating abundance and single-cell characteristics of respiring bacteria via the redox dye CTC. Aquat Microb Ecol 18: 117-131

B.F. Sherr, E.B. Sherr, del Giorgio PA (2001) Enumeration of total and highly active bacteria. Methods Microbiol 30: 129-159

E.B. Sherr, B.F. Sherr, Sigmon CT (1999) Activity of marine bacteria under incubated and in situ conditions. Aquat Microb Ecol 20:213-223

E.B. Sherr, B.F. Sherr, Verity PG (2002) Distribution and relation of total bacteria, active bacteria, bacterivory, and volume of organic detritus in Atlantic continental shelf waters off Cape Hatteras, NC, USA. Deep-Sea Res II 49: 4571-4585

Sieracki ME, Cucci TL, Nicinski J (1999) Flow cytometric analysis of 5-cyano-2,3-ditolyl tetrazolium chloride activity of marine bacterioplankton in dilution cultures. Appl Environ Microbiol 65:2409-2417

Smith EM (1998) Coherence of microbial respiration rate and cell-specific bacterial activity in a coastal planktonic community. Aquat Microb Ecol 16:27-35

Smith EM, del Giorgio PA (2003) Low fractions of active bacteria in natural aquatic communities? Aquat Microb Ecol 31:203-208

Smith JJ, McFeters GA (1997) Mechanisms of INT (2-(4iodophenyl)-3-(4-nitrophenyl)-5-phenyl tetrazolium chloride) and CTC (5-cyano-2,3-ditolyl tetrazolium chloride) reduction in Escherichia coli K-12. J Microbiol Methods 29:161-175

Søndergaard M, Danielsen M (2001) Active bacteria (CTC+) in temperate lakes: temporal and cross-system variations. J Plankton Res 23:1195-1206

Storedegger KE, Herndl GJ (2002) Distribution of capsulated bacterioplankton in the North Atlantic and North Sea. Microb Ecol 44:154-163

Swannell RPJ, Williamson FA (1988) An investigation of staining methods to determine total cell numbers and the number of respiring micro-organisms in samples obtained from the field and the laboratory. FEMS Microbiol Ecol 53: $315-324$

Ullrich S, Karrasch B, Hoppe HG, Jeskulke K, Mehrens M (1996) Toxic effects on bacterial metabolism of the redox dye 5-cyano-2,3-ditolyl tetrazolium chloride. Appl Environ Microbiol 62:4587-4593

Ullrich S, Karrasch B, Hoppe HG (1999) Is the CTC dye technique an adequate approach for estimating active bacterial cells? Aquat Microb Ecol 17:207-209

Whiteley AS, Griffiths RI, Bailey MJ (2003) Analysis of the microbial function diversity within water-stressed soil communities by flow cytometric analysis and CTC+ cell sorting. J Microbiol Methods 54:257-267

Winding AS, Binnerup SJ, Sørensen J (1994) Viability of indigenous soil bacteria assayed by respiratory activity and growth. Appl Environ Microbiol 60:2869-2875

Yager PL, Connelly TL, Mortazavi B, Wommack KE, Bano N, Bauer JE, Opsahl S, Hollibaugh JT (2001) Dynamic bacterial and viral response to an algal bloom at subzero temperatures. Limnol Oceanogr 46:790-801

Yu FP, McFeters GA (1994) Rapid in situ assessment of physiological activities in bacterial biofilms using fluorescent probes. J Microbiol Methods 20:1-10

Zimmermann R, Iturriaga R, Becker-Birck J (1978) Simultaneous determination of the total number of aquatic bacteria and the number thereof involved in respiration. Appl Environ Microbiol 36:926-935

Submitted: June 15, 2006; Accepted: October 19, 2006

Proofs received from author(s): January 7, 2007 